Наносистели, нанолатеріали, нанотехнології Nanosistemi, Nanomateriali, Nanotehnologii 2020 , т. 18, № 2, сc. 357-372
(C) 2020 ІМФ (Інститут металофізики ім. Г. В. Курдюмова НАН України) Надруковано в Україні. Фотокопіювання дозволено тільки відповідно до ліцензії

PACS numbers: 61.05.cp, 68.37.-d, 68.49.Sf, 68.55.jm, 78.30.-j, 81.15.Cd, 81.15.Gh

\title{
Nanosized Structure Formation by Trampoline Ion-Plasma Sputtering
}

\author{
A. M. Gabovich ${ }^{1}$, O. Yo. Gudymenko ${ }^{2}$, V. P. Kladko ${ }^{2}$, P. M. Lytvyn ${ }^{2}$, \\ Iu. M. Nasieka ${ }^{2}$, B. M. Romaniuk ${ }^{2}$, V. F. Semeniuk ${ }^{3}$, N. I. Semeniuk ${ }^{3}$, \\ V. V. Strelchuk ${ }^{2}$, V. I. Styopkin ${ }^{1}$, and V. M. Tkach ${ }^{4}$ \\ ${ }^{1}$ Institute of Physics, N.A.S. of Ukraine, \\ 46, Nauky Avenue \\ UA-03028 Kyiv, Ukraine \\ ${ }^{2} V$. E. Lashkaryov Institute of Semiconductor Physics, N.A.S. of Ukraine, \\ 41, Nauky Avenue \\ UA-03028 Kyiv, Ukraine \\ ${ }^{3}$ GreSem Innovation, LLC, \\ 46, Nauky Avenue \\ UA-03028 Kyiv, Ukraine \\ ${ }^{4} V$. M. Bakul Institute for Superhard Materials, N.A.S. of Ukraine, \\ 2, Avtozavodska Str., \\ UA-04074 Kyiv, Ukraine
}

The effect of collective trampoline ion-plasma sputtering on the surface properties of metals, insulators, and semiconductors is studied. The structure of the surface, composition and structure of films obtained by trampoline sputtering of various targets (metals, ceramics, silicon and carbon) are studied. The main parameters of the texturing processes and the formation of high-adhesive coatings are determined. As found, the resulting nanoscale surface structure provides extreme-adhesive fabricated films. In addition, the high rate of film deposition during ion-plasma treatment of the surface creates such submicron structures that the obtained dense films contain few defects.

Вивчається ефект колективного батутного йонно-плазмового розпорошення на поверхневі властивості металів, ізоляторів і напівпровідників. Досліджується структура поверхні, склад і структура плівок, одержаних батутним розпорошенням різних цілей (металів, кераміки, кремнію та вуглецю). Визначаються основні параметри процесів текстурування та формування високоадгезійних покриттів. Як було встановлено, одержана наномасштабна структура поверхні забезпечує екстремальну адгезію вироблених плівок. Крім того, висока швидкість осадження плівки під час йонно-плазмового обробляння поверхні створює 
такі субмікронні структури, що одержані щільні плівки містять мало дефектів.

Изучено влияние коллективного батутного ионно-плазменного распыления на поверхностные свойства металлов, изоляторов и полупроводников. Исследована структура поверхности, состав и структура плёнок, полученных методом батутного распыления различных мишеней (металлов, керамики, кремния и углерода). Определены основные параметры процессов текстурирования и формирования высокоадгезионных покрытий. Как установлено, полученная наномасштабная структура поверхности обеспечивает экстремальную адгезию полученных плёнок. Кроме того, высокая скорость осаждения плёнки при ионноплазменной обработке поверхности создаёт такие субмикронные структуры, что полученные плотные плёнки содержат мало дефектов.

Key words: trampoline sputtering, nanoscale structure, ultrahigh adhesion, nanoclusters.

Ключові слова: батутне розпорошення, наномасштабна структура, надвисока адгезія, нанокластери.

Ключевые слова: батутное распыление, наномасштабная структура, сверхвысокая адгезия, нанокластеры.

(Received 4 December, 2019)

\section{INTRODUCTION}

During deposition, the initial surface structure is an important factor that affects the physical characteristics of the surface and the properties of the deposited films [1]. Note that the ion-plasma film deposition is always accompanied by a preliminary preparation of the sample surface (see, e.g., [2]). The most effective known methods of surface preparation include heating a sample, processing in glow discharge plasma, bombarding the surface with beams of accelerated inert gas ions. Depending on the density and energy of ion fluxes, the state of the surface after ion bombardment can change significantly.

In gas-discharge systems intended to clean and activate the surface before coating (where the ion current density constitutes several $\mathrm{mA} / \mathrm{cm}^{2}$ and the energy is in the range of hundreds to thousands $\mathrm{eV}$ ), the sputtering of surface as a result of the ion bombardment leads to its polishing and smoothens the submicron relief.

At ion energies of tens of thousands $\mathrm{eV}$ and fluxes of about $10^{19}$ $\mathrm{cm}^{-2}$, sputtering by ions of inert gas can lead to the appearance of pyramidal structures of submicron scale on the surface of metal targets [3]. However, such treatment of the surfaces did not result 
in practically significant applications.

Technical characteristics of coatings depend both on the preliminary state of the substrate surface and on the parameters of the coating material flow. Fundamental requirements for the quality of functional coatings are as follow: (i) high adhesion of the coating to the base material; (ii) preservation of the multicomponent sputtered material composition; (iii) the absence or, at least, substantial reduction of coating defects. An important factor in obtaining a highquality coating is the high rate of its formation, when the influx of impurities into the coating film is minimized.

In this paper, the authors studied the texturing effects for the surfaces of metals, insulators, and semiconductors when exposed to collective trampoline ion-plasma sputtering found by us recently [4]. In particular, the trampoline sputtering leads to the formation of the surface structure on the target with two characteristic scales: nanoscale patterns (from several to tens of nanometres) and submicron structures (from hundreds to thousands of nanometres). In the case of ion-plasma deposition of films, nanoscale patterns ensure strong adhesion of films to the base and a high rate of film formation. Submicron structures give rise to dense films without defects. This roughness is the reason why there is practically no reflection of light in the visible wavelength range.

Trampoline sputtering leads to the release of the target material mainly in the form of nanoclusters with sizes from several to tens of nanometres. The sizes of the nanoclusters of the sputtered material depend on the trampoline sputtering modes and the type of material. For metals, the sizes of nanoclusters are the smallest, whereas when sputtering ceramics they are the largest. In trampoline sputtering, the film is formed mainly by nanoclusters. Therefore, the film is built essentially from the same material as the target multicomponent material. That is, the material is transferred from the target to the film without changing its composition. Such a nanocluster film emerges at a high speed that is one to two orders of magnitude higher than the film deposition rate for classic cascade sputtering in more traditional magnetron sputtering sources [5].

\section{EXPERIMENTAL EQUIPMENT AND RESEARCH METHODS}

The experiments were performed on the equipment [4], in which the ion-plasma flow with a density of up to $50 \mathrm{~mA} / \mathrm{cm}^{2}$ and with energy of up to $30 \mathrm{eV}$ is created by a helicon source. If a negative potential up to $700 \mathrm{eV}$ was applied to the sample holder, it is possible to increase the energy of ions that bombard the sample with practically unchanged plasma parameters in the region of plasma flow genera- 
tion. Such conditions allow us to study the effects associated with the formation of structures during the trampoline sputtering with varying ion energy but for other characteristics of ion-plasma flow being fixed.

The surface morphology of the targets after the treatment, the structure and composition of films formed by the trampoline sputtering were studied using scanning electron microscopy (SEM), atomic force microscopy (AFM), x-ray diffraction, Raman spectroscopy, secondary ion mass spectroscopy (SIMS) and energy-dispersion analysis. The parameters of the ion-plasma flow were controlled by measuring the ion current to the sample holder and the radio frequency (RF) power at a frequency of $13.56 \mathrm{MHz}$ absorbed in helicon-discharge plasma.

\section{EXPERIMENTAL RESULTS}

The trampoline sputtering demonstrates a threshold character and occurs when the ion current density on the $j^{+}$sample exceeds about $10 \mathrm{~mA} / \mathrm{cm}^{2}$, and the ion energy $E_{i}$ exceeds about 70-100 eV [4]. Nanoscale structures were formed more efficiently near the threshold values of the ion-plasma flow parameters. The surface structure depends on the initial state of the surface associated with its previous processing. At short exposure times, the pyramidal patterns of the nanostructure arise predominately in the regions of residual surface inhomogeneities. Figure 1 presents SEM micrographs of the surface of the single-crystal silicon wafers that were cut off by a

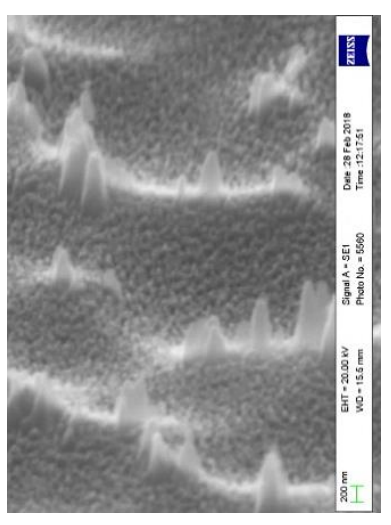

$a$

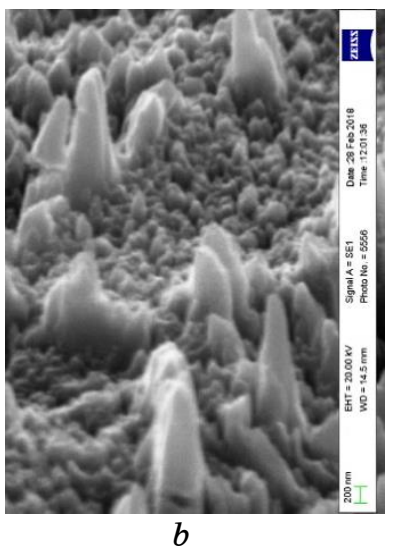

$b$

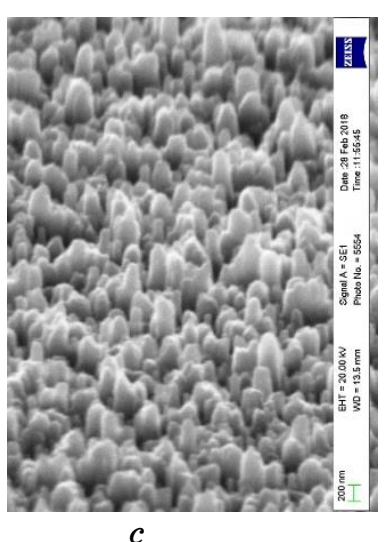

Fig. 1. SEM micrographs of the surface of single-crystal silicon wafers. $j^{+}=15 \mathrm{~mA} / \mathrm{cm}^{2}, E_{i}=200 \mathrm{eV}$ (see explanations in the text). The exposure times are $0.5 \min (a), 1 \mathrm{~min}(b), 5 \mathrm{~min}(c)$. 


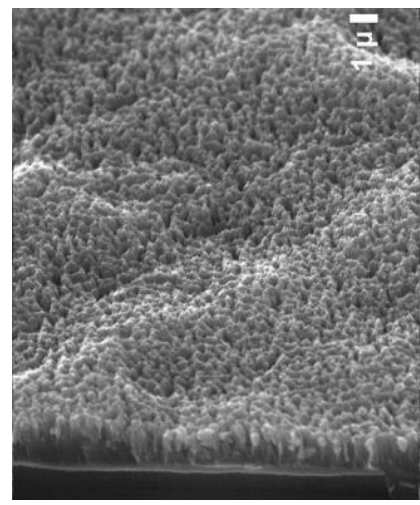

$a$

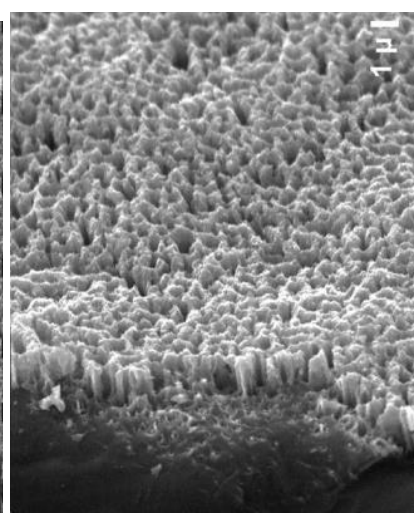

$b$

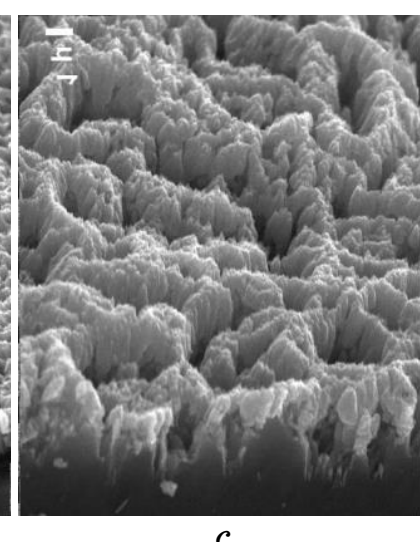

$c$

Fig. 2. SEM micrographs of the surface of single-crystal silicon wafers at various parameters of the trampoline sputtering (see the text).

diamond wire and underwent preliminary plasma-chemical etching to remove the defective layer. In Figure 1, $a, b, c$, the textures are shown obtained by increasing (from left to right) the ion bombardment fluence. In Figure 2, $a, b$, two texture scales are clearly visible, namely, nanoscale and submicron ones. With the intensification of the trampoline sputtering process, the texture changes, and the nanoscale structure appears as a modulation of the submicron structure.

In accordance with the previously mentioned, the trampoline sputtering occurs if the ion current density exceeds the threshold value $j_{\text {thr }}^{+}$. The appearance of the resulting texture is practically independent of the current density, but is determined by the temperature of the sample and the ion energy in the flow.

In Figure 2, $a, c$, the transformation of the single-crystal silicon texture is shown for various sputtering parameters (sample temperature, ions energy). The depth of texturing significantly exceeds the typical lateral size of the structure and equals to $1-2 \mu \mathrm{m}$. Thus, it is possible to control the size, shape and depth of the resulting texture by changing the temperature of the sample and the ion energy in the ion-plasma flow.

It should be also noted that the nature of the trampoline-induced structure of silicon depends on the type and degree of Si doping. The micrograph of Fig. 3 shows the texture of the single-crystal silicon samples with (i) a hole conductivity of $4.5 \mathrm{Ohm} \cdot \mathrm{cm}(a)$ and (ii) an electronic conductivity of $0.002 \mathrm{Ohm} \cdot \mathrm{cm}(b)$.

An increase in the energy of ions and an increase in the initial temperature of copper samples significantly affect the texture of the latter. A change in the texture scale in the submicron range 


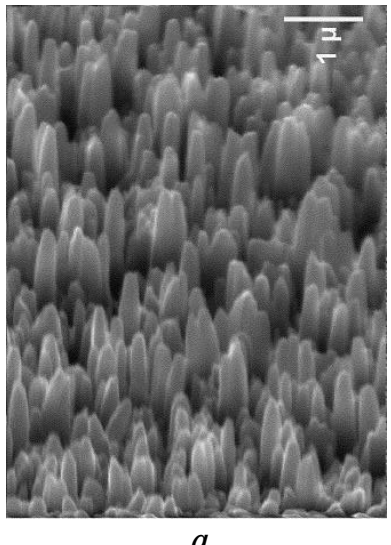

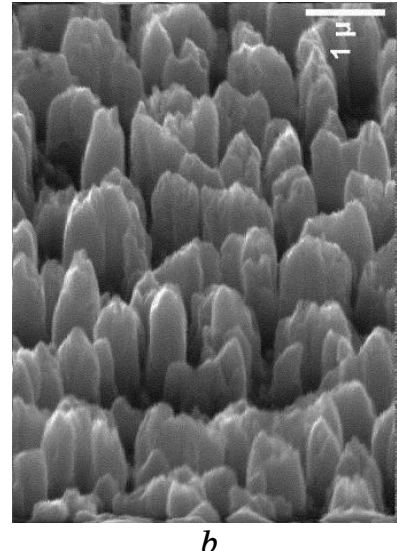

Fig. 3. SEM micrographs of the surface of single-crystal Si wafers of the trademarks KDB-4.5 (a) and KEM-0.002 (b) after a simultaneous trampoline sputtering.

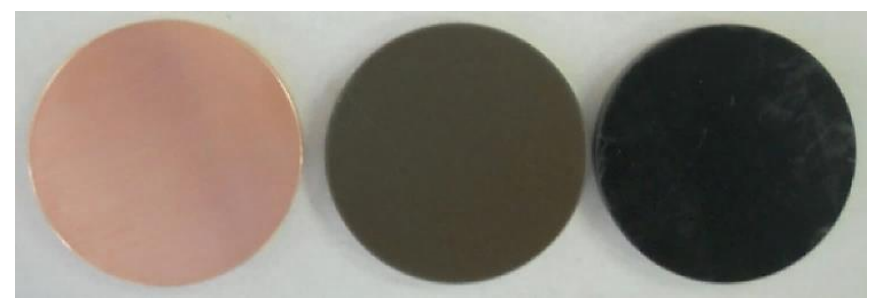

Fig. 4. Photographs of copper samples before and after trampoline sputtering.

leads to a change in the colour of the copper sample from natural red to brown and black. Figure 4 shows photographs of polished copper samples with a diameter of $30 \mathrm{~mm}$ and a thickness of $3 \mathrm{~mm}$, being of different colours. The transition from brown to black colour can be obtained either by increasing the ion energy in the plasma stream from 300 to $500 \mathrm{eV}$ or by preheating the sample to $100^{\circ} \mathrm{C}$ without changing the ion energy. SEM micrographs of the surface structure of the same copper samples as in Fig. 4 are shown in Fig. 5.

To exclude any connection of the black colour of the copper sample to a possible oxidation of its surface, studies of the Raman spectra were performed. In order to do this, the sample was placed on the radial boundary of the ion-plasma flow in the non-uniform treatment zone. The results representing the surface composition of the sample using Raman spectroscopy are shown in Fig. 6.

The measurements showed that, on the reverse, intact side of the 


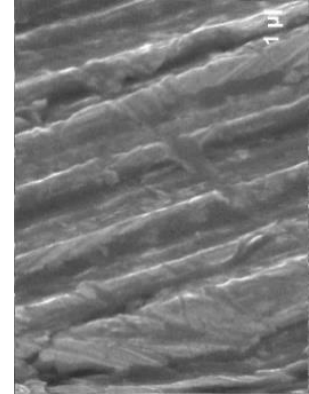

$a$

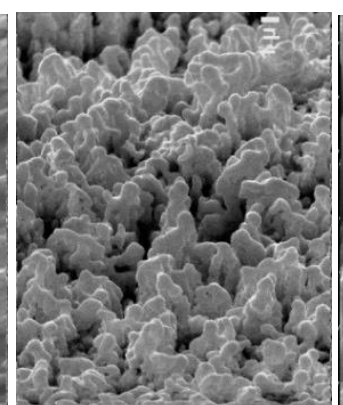

$b$

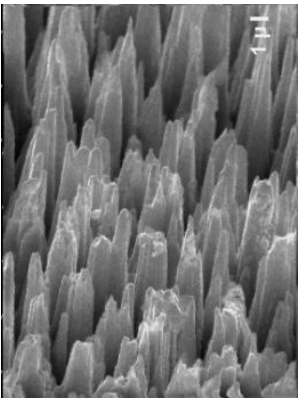

$c$

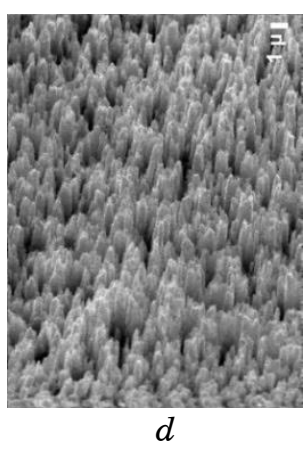

Fig. 5. SEM micrographs of the of copper sample surfaces at different values of the bombarding ion energy and the initial temperature, $(a)$ corresponds to the red copper, $(b)$ corresponds to the brown copper, whereas $(c)$ and $(d)$ represent the black copper.

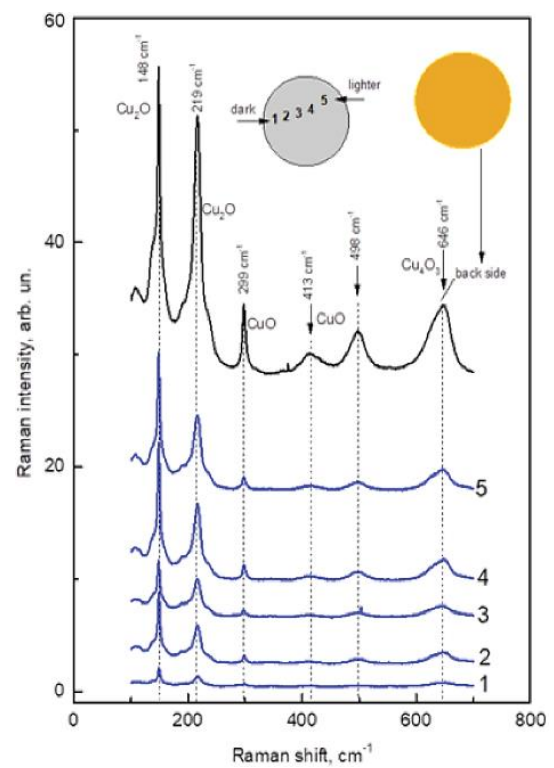

Fig. 6. Raman spectra of the copper sample surface.

sample, lines corresponding to copper oxides are present in the Raman spectrum.

On the side of the sample, which had been exposed to the ion flow in the trampoline sputtering regime, the intensity of lines due to copper oxides sharply decreases, approaching zero in the area of black copper while passing from a light-coloured sample to a blackcoloured one. The colour change of a copper sample during ion- 
plasma treatment is associated with the submicron surface structure with its size of the order of the visible light wavelength. This pattern is formed by trampoline sputtering along with the nanosize one.

The quality of functional coatings is determined by the state of the wafer surface, and its composition, and the structure of particles in the flow of a coating material. Trampoline sputtering leads to the nanoscale texturing of the wafer surface. We surmise that the ejection of the material during trampoline sputtering is due to the emission of not only individual atoms, but also the nanoscale clusters. This assumption supported by high trampoline sputtering coefficients [4], which are two orders of magnitude higher than the coefficients of a classical cascade sputtering [3]. Experiments on the formation of coatings during trampoline sputtering of targets from various materials confirm this assumption.

The composition and structure of films, which were formed during trampoline sputtering of pyrolytic graphite and such multicomponent materials as chromium-nickel stainless steel, perovskite ceramics, and highly-doped silicon, were also studied.

Figure 7 shows AFM images of the stainless steel $(a)$ and perovskite ceramics $(b)$ samples. These AFM images show that films during trampoline sputtering of materials are formed from nanoscale clusters. The size of those clusters lies within $9 \mathrm{~nm}$ with a root mean square roughness (RMS) of $0.37 \mathrm{~nm}$ for stainless steel and within $48 \mathrm{~nm}$ with $\mathrm{RMS}=2.35 \mathrm{~nm}$ for the perovskite ceramics.

The formation of films from nanoclusters of the target material makes it possible to preserve the multicomponent composition of the target in the obtained film. This is confirmed by the results of the energy dispersive analysis of the film and target compositions, which is shown in the Table in Fig. 8.

Trampoline sputtering of highly doped silicon of the trademark KEM-0.002 also ensures the preservation in the film of a dopant As. This is confirmed by the data in Fig. 9, which show the results of measuring the composition of the ceramics target and the deposited film, carried out using the method of mass spectrometry of secondary ions.

Raman spectroscopy studies showed that the trampoline sputtering transforms the pyrolytic graphite into a carbon composite, which contains structures with $s p^{3}$ hybridization, amorphous and clustered crystalline graphite with the structural fragments up to 5-9 nm (Fig. 10).

Note that in the plasma-enhanced chemical vapour deposition (PECVD) of silicon onto a stainless steel wafer with a surface, which was nanostructured by means of the trampoline sputtering, the films with a nanoscale structure were also formed. This is testi- 

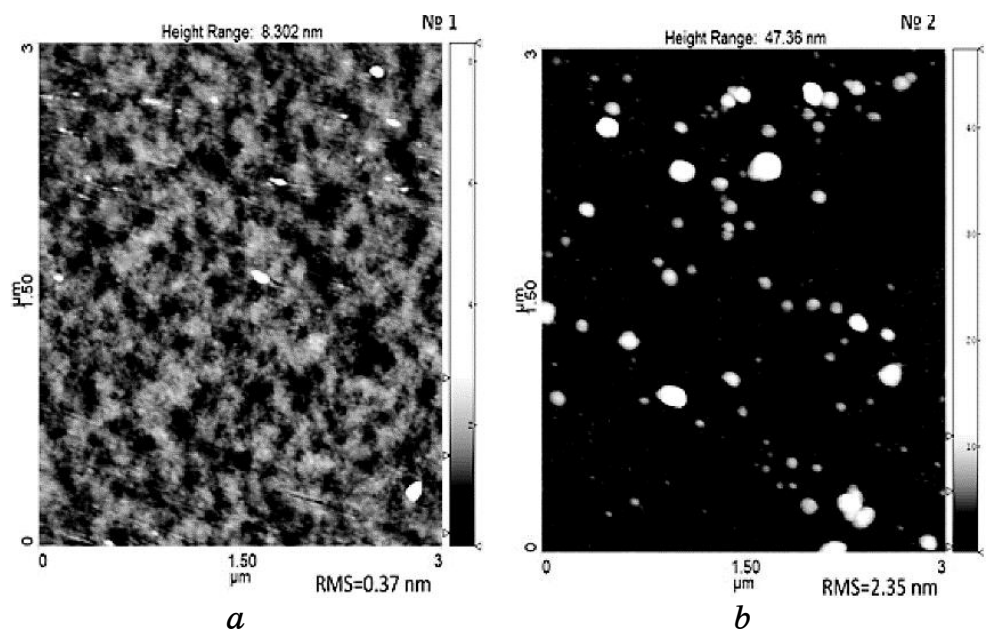

Fig. 7. AFM images of stainless steel films $(a)$ and perovskite ceramics $(b)$ formed by trampoline sputtering.

\begin{tabular}{c|c|c|c|c|c}
\hline \multicolumn{7}{c}{ Perovskite $\mathbf{L a}_{\mathbf{0 . 5 6}} \mathbf{L i}_{\mathbf{0 . 3 3}} \mathbf{T i O}_{3}$} \\
\hline \multicolumn{2}{c}{ Target } & \multicolumn{2}{|c}{ Film } \\
\hline \multirow{2}{*}{ Element } & weight \% & atom \% & Element & weight \% & atom \% \\
\hline OK & 37.41 & 73.33 & OK & 33.16 & 70.41 \\
\hline TiK & 29.23 & 19.14 & TiK & 25.85 & 18.33 \\
\hline LaL & 33.35 & 7.53 & LaL & 39.71 & 9.71 \\
\hline
\end{tabular}

Fig. 8. The compositions of the perovskite ceramics target and the film formed by the trampoline sputtering.

fied by the data of x-ray diffraction analysis presented in Fig. 11. The size of the coherent scattering regions is $2.1 \mathrm{~nm}$.

The nanoscale structure of the substrate surface creates the conditions for a strong adhesion, in particular, when sputtering complex composite materials. Namely, to make lithium-ion batteries (LIB), one needs to fabricate silicon composite anodes on a structured foil (current collector) [6,7]. In particular, copper is a typical material if a strong enough adhesion is ensured [8, 9]. However, this goal is not easy to achieve. As shown in SEM micrographs of Fig. 12, $a$, the necessary adhesion, which ensures the preservation of the electrode during LIB cycling, occurs only if the copper foil surface is properly textured at the nanoscale. We emphasize that 


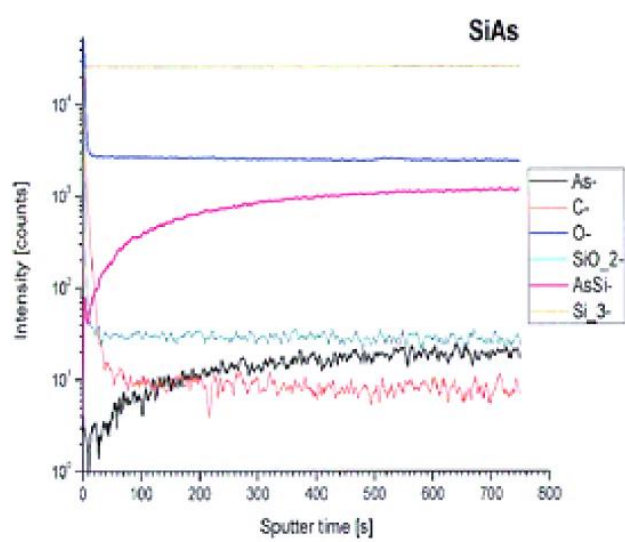

$a$

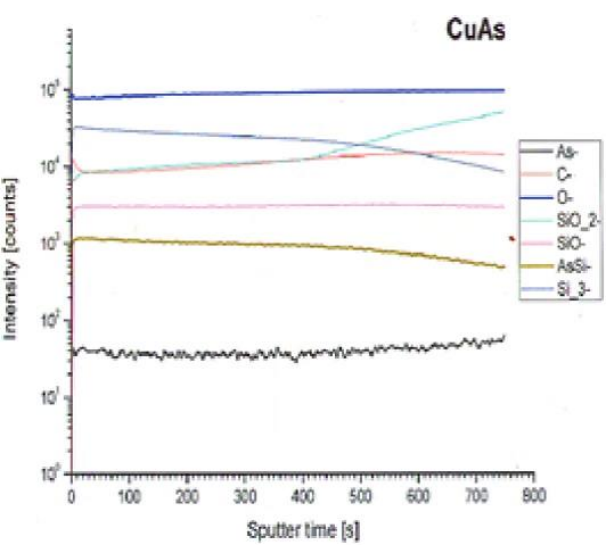

$b$

Fig. 9. The composition of the target $(a)$ and the film $(b)$ of highly doped silicon.

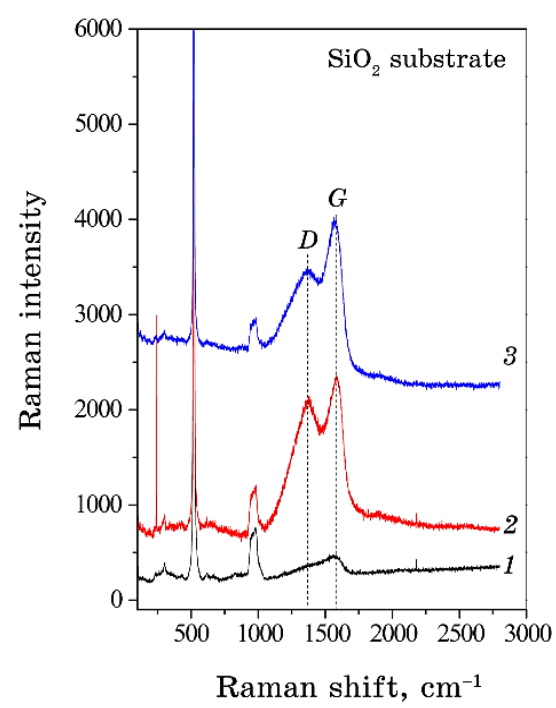

\begin{tabular}{c|c|c|c|c|c}
\hline Substrate & Sample, No. & $\omega_{G}$ & $I_{D} / I_{G}$ & $L_{a}, \AA$ & $s p^{3}$-cont. \\
\hline $\mathrm{SiO}_{2}$ & 1 & $1559 \mathrm{~cm}^{-1}$ & 0.5 & 88 & 0.34 \\
$\mathrm{SiO}_{2}$ & 2 & $1587 \mathrm{~cm}^{-1}$ & 0.83 & 53 & 0.20 \\
$\mathrm{SiO}_{2}$ & 3 & $1573 \mathrm{~cm}^{-1}$ & 0.7 & 62 & 0.27 \\
\hline
\end{tabular}

Fig. 10. Raman spectra of carbon structures formed by trampoline sputtering of the pyrolytic graphite.

this advantageous texturing was obtained only in the collective trampoline regime. 


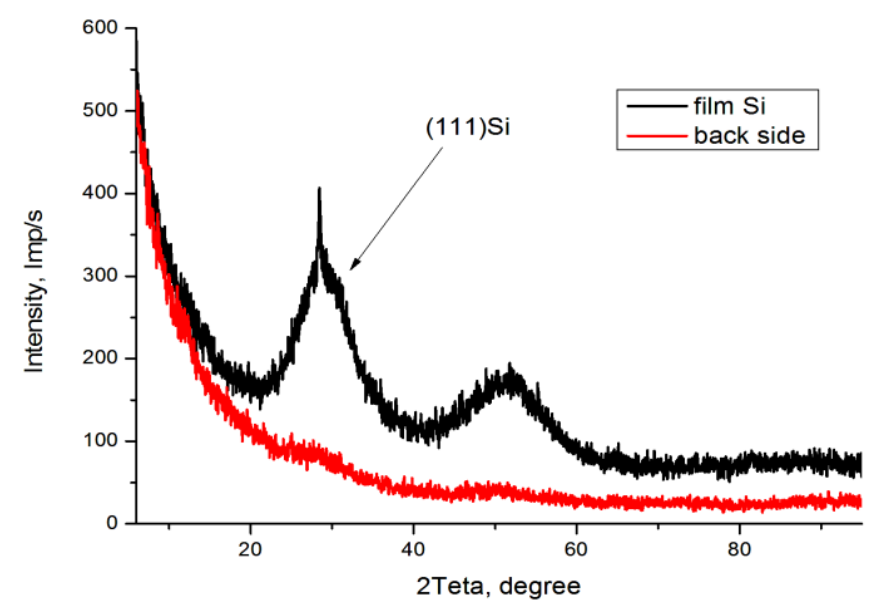

Fig. 11. Diffraction patterns of a nanocrystalline silicon film formed in the PECVD process on a nanostructured surface exposed to the trampoline sputtering (black curve) and the back of the sample (red curve).

The surface view of silicon composite film $8 \mu \mathrm{m}$ thick is presented on the left side of Fig. 12, $b$. If the structure of foil surface becomes such as in Fig. 12, $c$ (for example, it may happen due to the overheating of the foil during trampoline texturing), the composite anode material peels off already during the formation of the LIB anode. This situation corresponds to that shown on the right side of Fig. 12, $b$. In this case, the deposition rate of the silicon compositeanode material is reduced by $70 \%$. The same effects are observed during the fabrication of a silicon composite anode on an unstructured copper foil.

The strong adhesion of the silicon composite film to the copper foil is confirmed by the fact that the integrity of the anode is maintained after $300+$ LIB cycles for the anode, in which the active silicon fraction exceeds $50 \%$. Such an anode increases its volume by more than 1.5 times during lithiation. Despite the increase in the linear dimensions of the anode structure by almost $15 \%$, its integrity is maintained during the LIB cycling due to strong adhesion.

We studied the adhesion of the silicon composite $8 \mu \mathrm{m}$ thick to a copper foil $20 \mu \mathrm{m}$ thick. The tests were carried out by repetitive bending of the sample by $90^{\circ}$ until it broke. Actually, the structure of the 'foil plus silicon composite film' broke after 94 bending cycles. At the kink, there were no signs of peeling of film from the substrate.

SEM micrograph of fracture is shown in Fig. 13, where the presence of a transition layer up to $2 \mu \mathrm{m}$ thick is visible in the structure of a copper foil. Such a thickness of the transition layer is con- 


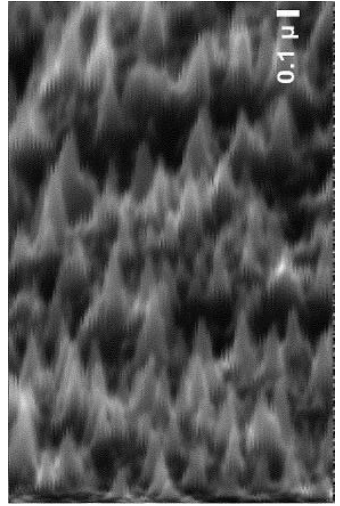

$a$
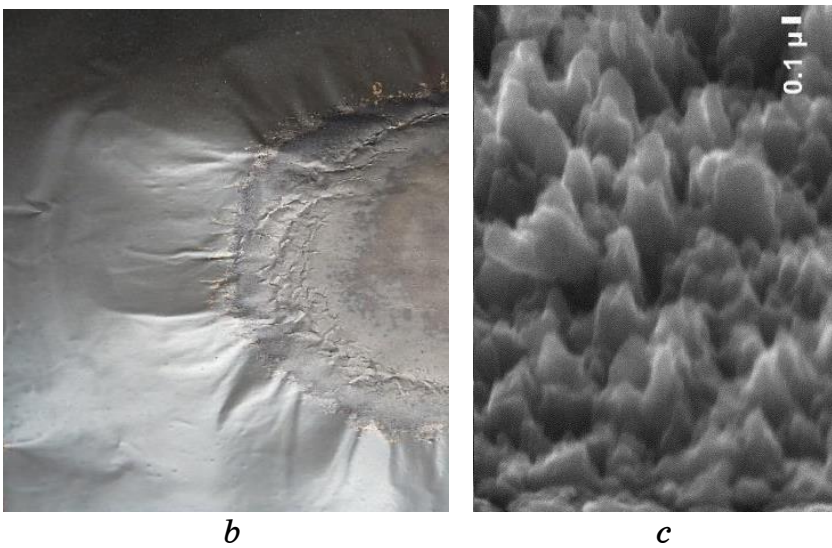

Fig. 12. SEM micrographs of the nanoscale $(a)$ and submicron $(c)$ surface structures of the copper foil after trampoline texturing. Photo of a silicon composite film is demonstrated in panel $(b)$.

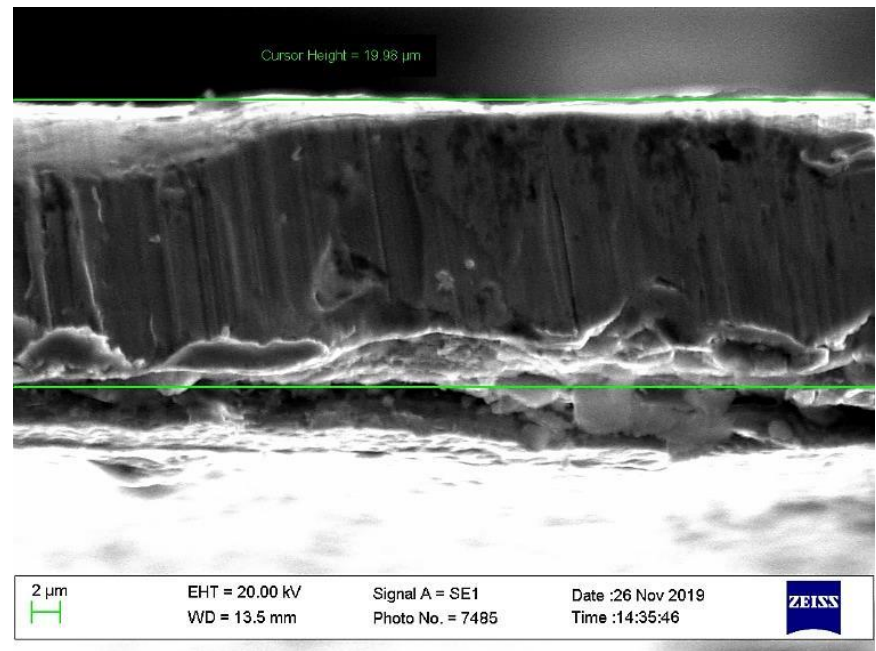

Fig. 13. SEM microphotograph of fractured structure consisting of the copper foil $20 \mu \mathrm{m}$ thick (the structure is seen within the cursors) and the silicon composite film $8 \mu \mathrm{m}$ thick.

sistent with the data of Fig. 2, where the depth of the texture after the trampoline sputtering constitutes about $2 \mu \mathrm{m}$.

Trampoline texturing eliminates strains that occur under the damaged layer when the silicon ingot is cut into wafers. Figure 14 shows a SEM photomicrograph, in which the localization of the strained zone is visible as a bright band under the dark zone of the 

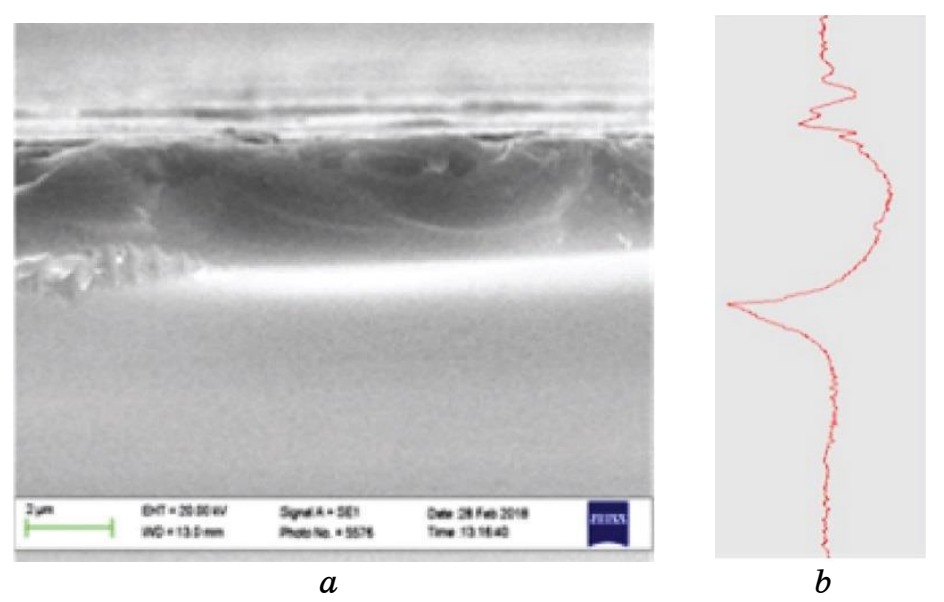

Fig. 14. SEM micrograph of the cleavage of a silicon wafer cut by a diamond wire.
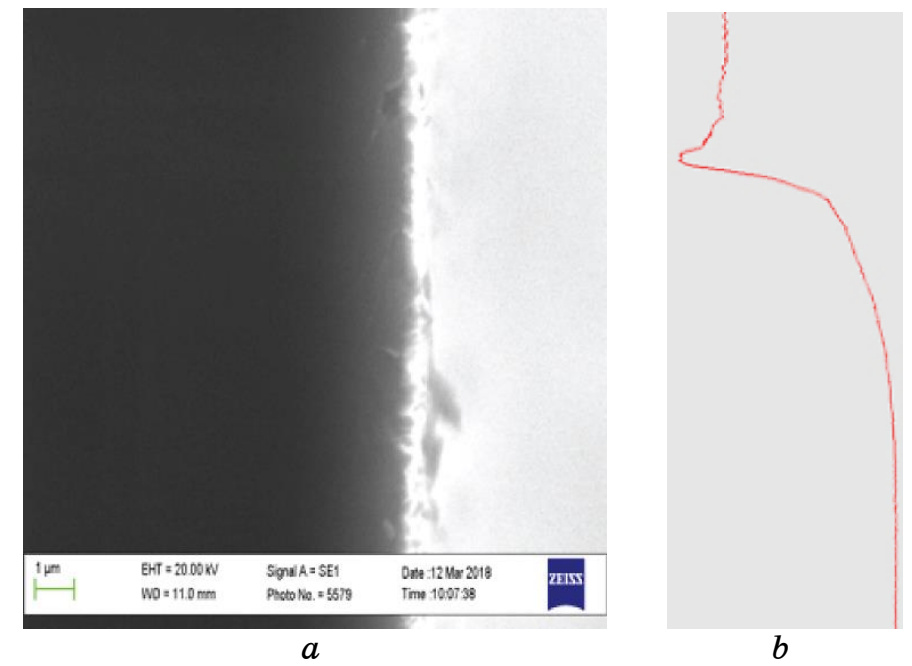

Fig. 15. SEM micrograph of the silicon wafer cleavage cut by a diamond wire after the damaged layer is removed by plasma chemical etching, and the trampoline texturing occurred.

damaged layer of about $4 \mu \mathrm{m}$ thick.

After eliminating the damaged layer and trampoline texturing of the surface, there are practically no strained areas in the bulk of the silicon wafer, as is visible in Fig. 15. Strains relax in the surface region of the microtexture with a thickness of less than $2 \mu \mathrm{m}$. 


\section{DISCUSSION OF THE RESULTS}

Experimental results show that, as a consequence of the trampoline sputtering of solid surfaces, two kinds of structures are formed. They are nanoscale and submicron structures patterns, strongly dependent on the parameters of the processes. However, the very appearance of the surface structure induced by the trampoline sputtering turned out to be universal and observed regardless of the type of material. In particular, it was found for metals, semiconductors, and oxide ceramics. For different materials, the characteristic sizes of nanoscale structures (from several to tens of nanometres) are different and depend on the fabrication conditions. Submicron structures can range in size from hundreds to thousands of nanometres.

Nanoscale structures ensure strong adhesion of films to the substrate during the formation of coatings from materials whatever their varying physical characteristics. It is important that high adhesion can be achieved without the application of transitional matching layers. The totality of measurements suggests the conclusion that the initial nanoscale texturing of the surface substantially modifies well-known elementary processes (such as secondary ion or electron emission) determining the substantial stages of the surface structure formation. The surface, severely distorted by the trampoline sputtering, remembers its modified state. This phenomenon makes the trampoline sputtering even more promising from the technological point of view in addition to its advantageously high productivity in target sputtering [4].

Nanosized structuring during trampoline sputtering creates the conditions for the formation of nanostructured coatings during subsequent film deposition in PVD and PECVD processes. In experiments on the formation of coatings on nanostructured surfaces, the rate of PVD and PECVD of the film deposition processes increased by $50-70 \%$ as compared with the rate of deposition on unstructured surfaces.

The submicron structure of the sample surface formed by the trampoline sputtering ensures the creation of dense defect-free films. Submicron patterns ensure conditions under which there is practically no reflection of light from such a surface in the visible wavelength range. Films that are formed by the trampoline sputtering are nanostructured. This is due to the fact, that the material is released both in the form of atoms and in the form of atomic nanoclusters that carry the bulk of the coating material. Therefore, the composition of the multicomponent sputtered material is retained in the coating films.

The surface is modified randomly at a nanoscale deep into the 
material bulk. Hence, the subsequent incident clusters of the coating material interact with the already modified surface. Such a randomization is universal and hides the individual characteristics of various materials. At the same time, the random structuring processes prevent the movement of defects from the bulk to the surface and prevent their consolidation, which reduces the likelihood of microcracks and destruction of the desired products during the processing. One can hope that, in such a way, the quality of other coatings obtained in the suggested regime of the film formation will remain high.

\section{CONCLUSION}

Structuring the surface at nano- and submicron scales and the ejection of nanoclustered material by trampoline sputtering creates the conditions for the formation of high-quality functional coatings with strong adhesion and preserving the multicomponent composition. The obtained films were substantially defectless and possessed the desired reflection properties in the visible light range.

The trampoline technology for producing functional coatings was applied successfully in the GreSem laboratory: (i) for the formation of silicon composite LIB anodes with an active silicon fraction of more than $50 \%$; (ii) in environmentally friendly ion-plasma processes for creating black silicon for photovoltaics; (iii) in technology of forming anti-corrosion wear-resistant coatings with a low coefficient of friction; (iv) in the technology of supercapacitors to modify the surface of the electrodes in order to increase adhesion to the active material and reduce the resistance of the transitional layers, etc.

\section{ACKNOWLEDGMENTS}

The work in the Institute of Physics was partially supported by the Project No. 22 of the 2018-2020 Scientific Cooperation Agreement between Poland and Ukraine as well as Grants Nos. 1.4.B-179 and VC-205.

\section{REFERENCES}

1. P. M. Martin, Handbook of Deposition Techniques for Films and Coatings. Science, Application, and Technology (Oxford: Elsevier: 2009).

2. R. Lu, J. Z. Wu, C. Varanasi, J. Burke, I. Maartense, and P. N. Barnes, J. Electronic Mater., 36: 1258 (2019); https://doi.org/10.1007/s11664-0070196-3. 
3. The Fundamental and Applied Aspects of Solids Sputtering (Ed. E. S. Mashkova) (Moscow: Mir: 1989) (Russian translation).

4. A. M. Gabovich, V. F. Semeniuk, and N. I. Semeniuk, J.Phys. D: Appl. Phys., 52: 185201 (2019); https://doi.org/10.1088/1361-6463/ab05a1.

5. H. Hartmann, V. N. Popok, I. Barke, V. von Oeynhausen, and K.-H. MeiwesBroer, Rev. Sci. Instrum., 83, Iss. 7: 073304 (2012); https://doi.org/10.1063/1.4732821.

6. T. Minato and T. Abe, Prog. Surf. Sci., 92, Iss. 4: 240 (2017); https://doi.org/10.1016/j.progsurf.2017.10.001.

7. Nanotechnology for Lithium-Ion Batteries (Eds. Y. Abu-Lebdeh and I. Davidson) (New York: Springer: 2013).

8. Advances in Lithium-Ion Batteries (Eds. W. A. van Schalkwijk and B. Scrosati) (New York: Kluwer Academic: 2002).

9. C. Mikolajczak, M. Kahn, K. White, and R. T. Long, Lithium-Ion Batteries Hazard and Use Assessment (New York: Springer: 2011). 